\title{
PEDAGOGI DAN TEKNOLOGI DALAM E-LEARNING Studi Kasus: Pengembangan E-Learning di Fakultas Tarbiyah dan Keguruan IAIN Raden Intan Lampung
}

\author{
Oleh: Indra Gunawan, ST, MT \\ Fakultas Tarbiyah dan Keguruan, IAIN Raden Intan Lampung \\ indra_6una1@yahoo.co.id
}

\begin{abstract}
Abstrak
Aspek pedagogi sangat berpengaruh terhadap pengembangan materi (content development) dan pembelajaran (learning) dengan memperhatikan teknik dan behavior interaksi antara dosen (lecturer) dan mahasiswa (students). Di sisi lain aspek teknologi berpengaruh terhadap pengembangan materi yang dinamis dan rich multimedia, serta menyediakan fiturfitur (features) komponen sistem e-learning. Mengintegrasikan kedua aspek tersebut dapat meningkatkan kualitas pengembangan materi yang didukung oleh system e-learning agar proses belajar-mengajar menjadi optimal. Subjective Analysis atas pengintegrasian kedua aspek tersebut dalam sistem e-learning yang digunakan-SCELE, menunjukkan bahwa lingkungan pembelajaran online dapat menghadirkan suasana sebagaimana pembelajaran konvensional.
\end{abstract}

Kata kunci: pedagogi, teknologi, e-learning, SCELE

\section{Pendahuluan}

Pada dasarnya system e-Learning terdiri dari 3 (tiga) komponen, yaitu Learning Management System (LMS), e-Content, dan e-Services. Ketiga komponen ini, unfortunately, dilakukan oleh tiga aktor yang berbeda. LMS, sebagai mesin dari system e-Learning dibuat oleh berbagai perusahaan swasta (WebCity, Blackboard, dan lain-lain) dan ada juga yang dibuat oleh masyarakat dengan menggunakan open source (Moodle, Sakai, dan lainlain). Sedangkan e-Content merupakan materi pembelajaran (learning materials) yang dikembangkan oleh guru, dosen, fasilator yang hendak mengajarkan materi tersebut kepada muridnya. Untuk mendukung system e-Learning agar berjalan sesuai dengan yang diharapkan, diperlukan tenaga pendukung (supporting staff) yang memberikan layanan elektronis (e-Service).

Ketiga aktor ini mempunyai karakteristik yang berbeda-beda, sementara yang menjadi objek dari ketiga aktor ini adalah students. Interaksi dari ketiga aktor tersebut dengan students, sangat erat kaitannya dengan teknologi dan pedagogi yang digunakan. Oleh karena itu, pengembangan dan penggunaan sistem eLearning harus dilakukan secara menyeluruh (holistic), bukan parsial. Manajemen sistem e-Learning harus bisa memanfaatkan ketiga aktor tersebut, agar proses belajar-mengajar (teaching and learning process) berjalan secara optimal. Untuk itu diperlukan suatu mekanisme untuk mengintegrasikan aspek teknologi dan pedagogi dalam sistem e-Learning. 


\section{Teknologi Sistem e-Learning}

Teknologi yang diperlukan dalam pengembangan system e-Learning dapat dibagi dalam tiga kelompok, yaitu teknologi komputer, teknologi komunikasi, dan teknologi untuk pengembangan aplikasi e-Learning (LMS) dan materi (content) pembelajaran. Spesifikasi teknis (technical specification) dari teknologi komputer dan komunikasi sangat standard, yaitu memiliki kemampuan menjalankan multimedia, dan bisa tersambung ke internet. Sedangkan spesifikasi teknis teknologi untuk pengembangan aplikasi LMS, harus mampu menghasilkan aplikasi berbasis web.

Aplikasi LMS yang kami kembangkan dinamakan Student-Centered E-Learning Envirinment (SCELE) berbasis Moodle. SCELE ini merupakan alat yang diperlukan untuk merepresentasikan aktivitas dan tingkah laku (activities and behavior) dari dosen, mahasiswa, dan tenaga pendukung (supporting staff) dalam melakukan proses belajar-mengajar. Activities and behavior tersebut diwujudkan kedalam berbagai fitur dalam aplikasi SCELE. Aktivitas dan tingkah laku yang utama berikut fitur-fiturnya dalam SCELE dapat dilihat dalam Tabel 1 berikut ini.
Untuk pembuatan materi pembelajaran, diperlukan berbagai alat pengembangan (development tools), seperti alat untuk membuat teks, gambar, animasi, audio dan video. Berbeda dengan pembelajaran conventional, dimana semua materi pembelajaran ini dikontrol sepenuhnya oleh dosen. Sehingga seorang dosen dapat melakukan adjustment dalam waktu seketika apabila, misalnya, materi yang diajarkan berjalan terlalu cepat atau terlalu lambat, melakukan improvisasi/inovasi untuk mengatasi boredom, ice-breaker dan lain sebagaimanya. Sementara dalam pembelajaran dengan e-learning, materi pembelajaran tersebut disajikan oleh fiturfitur terkait yang ada pada SCELE, prerecorded. Sehingga tidak ada kesempatan untuk memperbaikinya dalam waktu seketika, kecuali semuanya sudah terekam dan terwakili didalam materi pembelajaran. Untuk itulah dikembangkan materi elearning yang bisa memotivasi dan memicu (trigger) mahasiswa agar mampu melakukan pembelajaran mandiri (selflearning), tetapi tetap bisa di monitor oleh dosen. Salah satu karakteristik materi elearning yang dikembangkan ini adalah, dapat mendeteksi kemajuan aktivitas belajar mahasiswa. Mahasiswa diberikan kebebasan untuk menentukan tujuan dari pembelajarannya.

Tabel 1. Keterkaitan Aktivitas dengan Fitur-2 SCELE

\begin{tabular}{|l|l|l|l|}
\hline \multicolumn{1}{|c|}{ Aktivitas } & \multicolumn{1}{|c|}{ Pelaku } & \multicolumn{1}{c|}{ Fitur SCELE } & \multicolumn{1}{c|}{ Keterangan } \\
\hline $\begin{array}{l}\text { Menyusun materi } \\
\text { pembelajaran }\end{array}$ & Dosen/Guru & $\begin{array}{l}\text { Content } \\
\text { Management }\end{array}$ & $\begin{array}{l}\text { Bagaimana seorang guru melakukan } \\
\text { persiapan pengajaran (teaching) }\end{array}$ \\
\hline $\begin{array}{l}\text { Mengelola } \\
\text { administrasi } \\
\text { peserta }\end{array}$ & $\begin{array}{l}\text { Staff } \\
\text { Pendukung }\end{array}$ & $\begin{array}{l}\text { User } \\
\text { Management }\end{array}$ & $\begin{array}{l}\text { Staff pendukung memberikan layanan } \\
\text { e-administrative (access authority, } \\
\text { setting the dates, etc. }\end{array}$ \\
\hline $\begin{array}{l}\text { Memantau } \\
\text { interaksi kegiatan } \\
\text { akademik peserta }\end{array}$ & Dosen & $\begin{array}{l}\text { Bulletin board, } \\
\text { discussion } \\
\text { forum, e-mail }\end{array}$ & $\begin{array}{l}\text { Dalam hal ini, si dosen bisa } \\
\text { berkomunikasi dengan perserta secara } \\
\text { tertulis dan konsisten. }\end{array}$ \\
\hline
\end{tabular}


Disisi lain, system SCELE menyediakan forum diskusi untuk membahas berbagai permasalahan yang dipicu oleh materi pembelajaran tersebut. Dengan memperhatikan berbagai aspek tersebut, maka materi yang dikembangkan dikemas (packaging) dalam bentuk tiga level [5], yaitu materi level 1 sampai 3. Materi level satu dapat berupa teks, gambar, table, grafik, dan pointer keberbagai informasi lainnya. Materi level satu ini bersifat statis dan satu arah. Materi yang diberikan kepada mahasiswa adalah poin-poin yang penting saja. Tujuannya adalah untuk memfasilitasi mahasiswa yang hanya ingin melihat dengan cepat materi apa saja yang sudah-sedang-akan dibahas. Walaupun demikian mahasiswa didorong untuk menggali lebih dalam lagi mengenai materi yang diberikan, misalnya melalui tugas individu, kuis, dan lain sebagainya.

Materi level 2 berisi materi level satu yang diperkaya dengan multimedia: teks, visual, audio, video, animasi, dan intelligent learning object [6][7]. Disamping itu, materi level 2 ini diperkaya dengan adanya narasi, catatan pinggir, dan pemicu (trigger). Pemicu ini dibuat dalam bentuk cerita singkat tentang suatu kasus real yang terjadi. Kemudian mahasiswa diminta untuk membahas pemicu ini secara berkelompok. Untuk memulai pembahasan, mahasiswa dipandu dengan beberapa pertanyaan yang berkenaan dengan studi kasus tersebut. Keluaran pembahasan ini adalah berupa tanggapan terhadap studi kasus yang diberikan. Tujuan dari materi level 2 ini adalah untuk mendorong agara mahasiswa lebih aktif membaca materi pembelajaran dan memberikan respon terhadap materi tersebut. Pada level ini, semua materi pembalajaran sudah sudah direkam terlebih dahulu.
Materi level 3 berisi materi yang dapat memberikan nilai tambah terhadap topik yang sedang dibahas. Materi level 3 merupakan materi lepas yang berisikan latar belakang pengetahuan tentang suatu topik dan memberikan tambahan informasi atau pengetahuan kepada mahasiswa yang ingin memperdalam suatu topic tersebut. Materi tersebut dapat dibuat sendiri oleh dosen berupa file dokumen, presentasi, referensi kepada suatu link/website, dsb. Tujuan dari materi level 3 ini adalah untuk memfasilitasi mahasiswa yang akan "go beyond” topik yang sedang dibahas dengan memperhatikan keterkaitan suatu topik dengan topik yang lain. Topik-topik yang terkait bisa saja berasal dari bidang ilmu yang berbeda. Materi level 3 ini bersifat dinamis, dimana mahasiswa dapat merespon secara langsung terhadap materi yang disajikan. Hal ini akan memicu mahasiswa dan dosen untuk mendapatkan temuan-temuan (discoveries) ide baru untuk penelitian.

Aspek teknologi pada LMS dan materi (content) tidak akan optimal kalau tidak diikuti oleh aspek pedagogi yang benar. Setelah LMS dan materi pembelajaran dibuat dengan berbagai karakateristik yang merepresentasikan keperluan dosen dan mahasiswa untuk belajar-mengajar, maka langkah berikutnya adalah bagaimana melaksanakan proses belajar-mengajar itu sendiri secara optimal. Untuk itu diperlukan pemahaman pedagogi, yang akan dibahas pada bagian berikut ini.

\section{Aspek Pedagogi dalam e-Learning}

Pedagogi (pedagogy) adalah merupakan seni atau ilmu mengajar--the art or science of teaching. Dari segi bahasa ada perbedaan antara pedagogi dan andragogi. Pedagogi adalah bagaimana cara mengajar anak- 
anak, sedangkan andragogi adalah bagaimana cara mengajar orang dewasa [2]. Menurut Bruner, ada empat model pembelajaran, yaitu: Learning by being shown; Learning by being told; Learning by constructing meaning and; Learning by joining a knowledge-generating community [8]. Dari keempat model tersebut, Bjorke dkk mengajukan suatu model pendekatan pedagogi yang terpadu yang terdiri dari pendekatan Instructional, Constructivist, dan Social Constructivist (lihat Gambar 1) [9]. Ketiga pendekatan pedagogi ini diadopsi secara terpadu di dalam sistem elearning yang kami kembangkan. Pada table 2 berikut ini, diperlihatkan keterkaitan antara karakteristik masingmasing pedagogi dengan teknologi system e-learning yang digunakan.

\section{Hasil Uji Coba}

Implementasi e-learning di Fakultas Tarbiyah dan Keguruan, IAIN Raden Intan Lampung menggunakan pendekatan dualmode, dimana pertemuan tatap muka dikombinasikan dengan e-learning. Jumlah sesi yang menggunakan tatap muka versus e-learning pada masingmasing mata kuliah, bervariasi satu sama lain. Tetapi telah ditetapkan, bahwa pertemuan tatap muka tidak boleh kurang dari 30\% dari total keseluruhan pertemuan.

Uji coba teknologi yang digunakan untuk SCELE, menghasilkan tingkat kepuasan yang sangat tinggi (94\%) dikalangan 47 orang mahasiswa yang menjadi responden [5]. Dalam hal ini, dapat disimpulkan bahwa fitur-fitur yang ada pada SCELE sudah sangat memadai untuk mendukung terlaksananya proses belajar-mengajar. Lebih jauh lagi, fitur-fitur yang ada pada SCELE tersebut sudah cukup baik untuk mengakomodir keperluan pengajar dan pembelajar yang secara pedagogis merupakan pendekatan kombinasi instructional, constructivist, dan social constructivist (lihat Tabel 2). Masalah terbatasnya bandwidth adalah satu-satu masalah yang menyebabkan kinerja sistem e-learning menjadi turun. Terutama untuk menjalankan materi level 2 dan 3 yang biasanya berisikan animasi, suara dan video. Untuk menjalankan materi yang demikian dalam suatu jaringan dengan kecepatan bandwidth hanya 2 Mbps, memerlukan waktu yang relatif lama.

Tetapi dari segi content, materi yang disajikan secara e-learning masih belum sebaik materi yang disajikan melalui tatap muka. Hanya 46.8\% dari para respondent yang mengatakan materi online lebih baik dari pada materi yang disajikan melalui tatap muka. Sebagian mahasiswa masih merasa bahwa pemberian materi secara tatap muka masih lebih menyenangkan ketimbang melalui e-learning.

Apabila digali lebih jauh lagi, mengapa pemberian materi secara tatap muka dianggap masih lebih baik, berikut beberapa komentar subjektif para responden.

- Materi yang diberikan sangat menoton, tidak ada masa jeda (pause). Kalau pun masa jeda, belum tentu sesuai dengan "pace” si pembelajar.

- Materi yang diberikan terasa sangat "sunyi-senyap", tidak ada background suara, sehingga yang terdengar adalah suara dan gambar dosennya.

- Materi yang disajikan belum bisa membangkitkan motivasi belajar para mahasiswa.

- Materi kurang menarik. 


\begin{tabular}{|c|c|c|c|c|}
\hline $\begin{array}{c}\text { Tipe } \\
\text { Pedagogi }\end{array}$ & Karakteristik & $\begin{array}{l}\text { Fitur-2 LMS } \\
\text { (SCELE) }\end{array}$ & Content & Metode Delivery \\
\hline \multirow[t]{4}{*}{$\begin{array}{l}\text { Instructional } \\
\text { (facilitated } \\
\text { learning) }\end{array}$} & $\begin{array}{l}\text { Traditional, } \\
\text { teacher-focused }\end{array}$ & $\begin{array}{lr}\text { Fasilitas } & \text { untuk } \\
\text { menyimpan } & \text { materi } \\
\text { pembelajaran }\end{array}$ & $\begin{array}{l}\text { Teks, gambar, } \\
\text { audio, video }\end{array}$ & \multirow{4}{*}{$\begin{array}{l}\text {-Pertemuan tatap } \\
\text { muka (face to } \\
\text { face). } \\
\text {-Mahasiswa } \\
\text { sebagai } \\
\text { pendengar. } \\
\text {-Kontrol } \\
\text { Teaching- } \\
\text { Learning pada } \\
\text { Dosen. }\end{array}$} \\
\hline & \begin{tabular}{|l} 
Learners \\
dependent on \\
teacher, \\
\end{tabular} & $\begin{array}{l}\text { Pertanyaan } \\
\text { diposting via e-mail }\end{array}$ & & \\
\hline & $\begin{array}{l}\text { Learners as rather } \\
\text { passive receptors }\end{array}$ & $\begin{array}{l}\text { Materi pembelajaran } \\
\text { tersedia dalam } \\
\text { setiap sesi }\end{array}$ & $\begin{array}{l}\text { Link } \\
\text { keberbagai } \\
\text { materi } \\
\text { pembelajaran }\end{array}$ & \\
\hline & $\begin{array}{l}\text { Sees "knowledge" } \\
\text { as fairly static and } \\
\text { objective. }\end{array}$ & $\begin{array}{lr}\text { Sesi-sesi } & \\
\text { pembelajaran } & \text { bisa } \\
\text { ditambah } & \text { sesuai } \\
\text { kebutuhan } & \end{array}$ & $\begin{array}{l}\text { Design materi } \\
\text { kedalam } \\
\text { sillaby }\end{array}$ & \\
\hline \multirow{5}{*}{$\begin{array}{l}\text { Constructivist } \\
\text { (individual } \\
\text { learning) }\end{array}$} & Active learners. & Discussion forum & $\begin{array}{l}\text { Materi pemicu } \\
\text { (trigger) }\end{array}$ & \multirow{5}{*}{$\begin{array}{l}\text {-Pertemuan } \\
\text { secara elektronis. } \\
\text {-Dosen sebagai } \\
\text { fasilitator. } \\
\text {-Feedback dosen } \\
\text { sesuai dengan } \\
\text { kemajuan } \\
\text { pembelajaran } \\
\text { mahasiswa. } \\
\text {-Kontrol ada pada } \\
\text { mahasiswa. }\end{array}$} \\
\hline & \begin{tabular}{|l|} 
Learners construct \\
their knowledge
\end{tabular} & Notes taking & $\begin{array}{l}\text { Guided } \\
\text { question and } \\
\text { answers }\end{array}$ & \\
\hline & \begin{tabular}{|l} 
Subjective, \\
dynamic \\
expanding
\end{tabular} & $\begin{array}{l}\text { Pointes to other } \\
\text { sources of learning }\end{array}$ & $\begin{array}{l}\text { Other sources } \\
\text { of learning }\end{array}$ & \\
\hline & $\begin{array}{l}\text { Processing and } \\
\text { understanding of } \\
\text { information }\end{array}$ & Pace setting & $\begin{array}{l}\text { Sequence of } \\
\text { learning } \\
\text { materials } \\
\text { (graph course } \\
\text { content) }\end{array}$ & \\
\hline & $\begin{array}{l}\text { Learner has his } \\
\text { own learning. }\end{array}$ & Personalization & $\begin{array}{l}\text { Setting } \\
\text { Learning } \\
\text { objectives } \\
\text { (graph } \\
\text { assessment) }\end{array}$ & \\
\hline \multirow[t]{4}{*}{$\begin{array}{l}\text { Social } \\
\text { Constructivist } \\
\text { (collaborative } \\
\text { learning) } \\
\end{array}$} & $\begin{array}{l}\text { Student joins a } \\
\text { knowledge- } \\
\text { generating. }\end{array}$ & Chat mode & Case study & \multirow{4}{*}{ 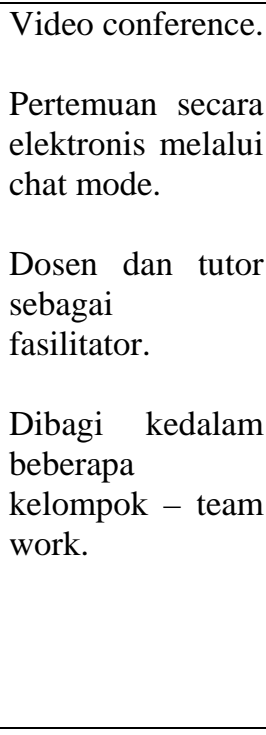 } \\
\hline & $\begin{array}{|ll|}\begin{array}{l}\text { Solve } \\
\text { problems }\end{array} & \text { real } \\
\end{array}$ & Chat mode & 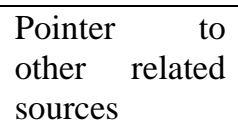 & \\
\hline & $\begin{array}{l}\text { Teacher will } \\
\text { himself be a } \\
\text { learner together } \\
\text { with his students. } \\
\end{array}$ & Video conference & 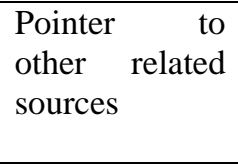 & \\
\hline & $\begin{array}{l}\text { The tasks will be } \\
\text { processing and } \\
\text { assessing } \\
\text { knowledge and } \\
\text { generating and co- } \\
\text { constructing new } \\
\text { knowledge. }\end{array}$ & Bulletin board & $\begin{array}{l}\text { Posting } \\
\text { conclusion, } \\
\text { solutions, and } \\
\text { evaluation of } \\
\text { each group. }\end{array}$ & \\
\hline & & & & \\
\hline
\end{tabular}




\section{Lesson Learned}

Kalau dilihat dari hasil evaluasi sistem elearning yang ada di Fak. Tarbiyah IAIN RI, maka dapat disimpulkan bahwa titik terlemahnya ada pada materi pembelajaran atau content, dan metode penyampaian (delivery method) dari content tersebut. Dari segi teknologi, kecuali bandwidth yang masih terbatas, sistem e-learning (SCELE) yang digunakan, sudah cukup memuaskan.

Berbagai cara telah dilakukan untuk meningkatkan kualitas sistem e-learning ini, diantaranya:

Dosen:

- Memberikan fasilitas laptop, berikut audio flashdisk recorder pada para dosen. Ternyata fasilitas yang lengkap, belum menjamin para dosen mau membuat materi yang berkualitas. Merubah materi yang disajikan di depan kelas kedalam sistem e-learning, memerlukan usaha yang besar. Tetapi untuk mendorong dosen membuat materi yang baik saja untuk disajikan didepan kelas, sudah merupakan suatu terobosan. Momentum sistem elearning menjadi pemicu bagi dosen untuk memperbaharui materi pembelajarannya dan syllabus.

- Membuat panduan (guideline) bagi dosen dalam menggunakan SCELE.

- Membuat panduan bagi dosen untuk membuat materi pembelajaran.

Mahasiswa:

- Membuat panduan (guideline) bagi mahasiswa dalam mengikuti e-learning.

Tenaga Pendukung (Supporting Staff):

- Menyediakan tenaga pendukung untuk merekam (audio dan video) dosen yang sedang mengajar, untuk setiap sesi dalam satu semester. Kegiatan ini menghasilkan file rekaman audio/video dengan ukuran Giga bytes! Ukuran file yang besar menyebabkan sulit untuk dioperasikan dalam sistem SCELE.

- Memperkuat tenaga pendukung yang bekerja di belakang layar. Tenaga pendukung ini terdiri dari programmer, script writer, instructional designer. Mereka bertugas untuk melakukan audio/video streaming, dan sinkronisasi dengan teks, gambar, grafik dari materi pembelajaran.

- Menyediakan tenaga narator yang membacakan materi pembelajaran yang telah ditulis oleh dosen. Tenaga narator digunakan untuk menggantikan suara dosen yang kurang "inspiring” untuk di dengar.

Manajemen:

- Membuat peraturan akademik yang berlaku sama, baik untuk konventional maupun untuk e-learning.

o Partisipasi dan kehadiran mengikuti perkuliahan

o Penalty terhadap keterlambatan menyerahkan tugas-tugas pembelajaran

- Menyediakan akses internet, dan ruangan e-learning

- Membuat kebijakan (policy) yang mendorong penggunaan e-learning untuk meningkatkan kualitas proses belajarmengajar di Fak. Tarbiyah IAIN RI.

Yang tidak kalah pentingnya, kegiatan penelitian dalam bidang e-learning menjadi lebih intensif, terutama bagaimana mengoptimalkan pemanfaatan teknologi dengan pedagogi yang optimal. Saat ini kegiatan penelitian ini difokuskan kepada pembuatan fitur personalisasi dan kolaborasi pada SCELE dan pembuatan 
intelligent learning object dan active learning material dengan kombinasi ketiga pendekatan pedagogi: instructional, constructivist, dan social constructivist.

Hasil sampingan lainnya dalam penerapan e-Learning di lingkungan Fakultas Tarbiyah dan Keguruan IAIN RI adalah sistem ini telah memberikan dampak yang sangat positif dalam perbaikan suasana akademik (academic atmosphere). Dari sisi manajemen, dengan adanya materimateri pembelajaran yang tersedia dalam e-learning, memudahkan pihak manajemen untuk memantau kesiapan para dosen untuk mengajar. Disamping itu, manajemen dapat memonitor mutu pembelajaran yang diberikan seorang dosen, yang sesuai dengan panduan penjaminan mutu (quality assurance) IAIN Raden Intan Lampung.

\section{Penutup}

Penerapan system e-learning melibatkan banyak actor, yaitu: industri LMS, industri development tools untuk content development, content developer (lecturer, programmer, instructional designer), dan content deliverer. Sementara yang menjadi object dari para actor ini adalah siswa (students). Nature dari para aktor ini berbeda satu sama lainnya. Para actor ini dapat dikelompokkan kedan dua kategori, yaitu: acktor teknologi (industri LMS, dan development tools), dan actor pedagogi (content developer dan content deliverer). Aktor pedagogi tidak bisa mengontrol actor teknologi, tetapi mereka bisa mengoptimalkan apa yang dibutuhkan untuk pembelajar (peserta didik).

Sesuai dengan hasil evaluasi uji coba penerapan sistem e-learning di Fak. Tarbiyah IAIN RI, permasalahan utama adalah pada materi pembelajaran dan cara pengajarannya, dibandingkan masalah teknologinya. Untuk itu, diperlukan pengkajian yang terus menerus, untuk mendapatkan materi dan cara pengajaran yang bisa membuat orang belajar (make learner learning). Hasil integrasi pendekatan pedagogis dan teknologi dalam system e-learning, sangat membantu dalam memahami kebutuhan peserta didik.

Saat ini, sistem e-learning di Fak. Tarbiyah IAIN RI, bukan untuk menggantikan pembelajaran konvensional, tetapi dipergunakan sebagai komplemen dari pembelajaran konvensional. Oleh karena itu, strateginya diterapkan secara bertahap dalam bentuk dual-mode (ada sesi yang dideliver melalui tatap muka dan ada sesi yang di deliver melalui e-learning). Tetapi semua materi perkuliahan tersedia juga dalam bentuk e-learning. Sejauh ini, penerapan e-learning sangat membantu peningkatan suasana belajar-mengajar di Fak. Tarbiyah IAIN RI.

\section{Referensi}

[1] Garrison, D. R., T. Anderson and W. Archer. Critical Thinking, Cognitive Presence and Computer Conferencing in Distance Education. American Journal of Distance Education 15(1): 7-23, 2001.

[2] http://en.wikipedia.org/wiki/Pedagogy, access date: 5 September 2006

[3] Hasibuan, Zainal A., dan Harry B. Santoso. "The Use of E-Learning towards New Learning Paradigm: Case Study Student Centered E-Learning Environment at Faculty of Computer Science University of Indonesia”. ICALT Conference, Taiwan, 2005.

[4] Hasibuan, Zainal A., dan Harry B. Santoso. "Issues and Strategies to Develop Learning Management System and Content Development”. ISEL Conference, Kinibalu, Malaysia, 2005. 
[5] Min, Rik, "Introduction in the six dimensions (of a multimedia product)", Center of Telematics and Information Technology, CTIT, University of Twente. [6] Liang-Kao Chang, Kuo-Yu Liu, Chien-An Wu, Herng-Yow Chen, "Sharing Web-Based Multimedia Learning Objects Using NNTP News Architecture," icalt, pp. 710-714, Fifth IEEE International Conference on Advanced Learning Technologies (ICALT'05), 2005.

[7] Bruner J.S. "Folk pedagogy; in The Culture of education", Cambridge MA, Harvard univ. press. 1996.

[8] Bjørke, Åke, et.al. "Global cooperation on e-learning: Background and pedagogical strategy" United Nations University/Global Virtual University, 2005. 